\title{
Estragole-rich essential oil of summer savory (Satureja hortensis L.) as an eco-friendly alternative to the synthetic insecticides in management of two stored-products insect pests
}

\author{
Asgar EBADOLLAHI ${ }^{1,2}$
}

Received October 29, 2019; accepted March 22, 2020.

Delo je prispelo 29. oktobra 2019, sprejeto 22. marca 2020

Estragole-rich essential oil of summer savory (Satureja hortensis L.) as an eco-friendly alternative to the synthetic insecticides in management of two stored-products insect pests

Abstract: The lesser grain borer [Rhyzopertha dominica (Fabricius, 1792)] and the red flour beetle [Tribolium castaneum (Herbst, 1797)] are among the cosmopolitan damaging pests on several stored-products. The overuse of chemical pesticides in the control of such pests caused several side-effects including environmental contaminations, human health problems, and insect pests' resistance. In this circumstance, researchers have focused on safe and effective alternatives to chemical pesticides. In the present study, the insecticidal efficiency of essential oil extracted from the summer savory (Satureja hortensis L.) was assessed on the $R$. dominica and $T$. castaneum adults. The chemical profile of essential oil was evaluated through a gas chromatography-mass spectrometer, in which estragole, $\beta$-ocimene and d-limonene were the main components. The essential oil had considerable fumigant toxicity on insect pests. The mortality of insects was dependent on the essential oil concentration and exposure time. Probit analysis indicated that $R$. dominica with low $\mathrm{LC}_{50}$ values (Lethal Concentration to kill $50 \%$ of tested insects) was more susceptible than T. castaneum. Accordingly, S. hortensis essential oil with a high level of phenylpropanoid and terpenic compounds can be recommended as an efficient and natural alternative to the detrimental chemicals in the management of $R$. dominica and T. castaneum.

Key words: essential oil; estragole; Satureja hortensis; fumigation; coleopteran pests
$\mathrm{Na}$ estragolu bogato eterično olje vrtnega šetraja (Satureja hortensis L.) kot okolju prijazna alternativa sintetičnim insekticidom pri zatiranju dveh vrst skladiščnih škodljivih žuželk Izvleček: Žitni kutar [Rhyzopertha dominica (Fabricius, 1792)] in rižev mokar [Tribolium castaneum (Herbst, 1797) sta kozmopolitski vrsti škodljivcev, ki povzročata škodo na mnogih uskladiščenih pridelkih. Prekomerna raba insekticidov pri zatiranju takšnih škodljivcev ima številne stranske učinke, vključno $\mathrm{z}$ onesnaževanjem okolja, zdravstvenimi problemi ljudi in odpornostjo škodljivih žuželk. V tej raziskavi so se raziskovalci osredotočili na varno in učinkovito alternativo sintetičnim insekticidom. Insekticidna učinkovitost eteričnega olja iz vrtnega šetraja (Satureja hortensis L.) je bila preizkušena na odraslih osebkih obeh vrst zgoraj omenjenih škodljivcev. Kemična sestava eteričnega olja je bila ovrednotena s plinskim kromatografom in masnim spektrometrom, ugotovljeno pa je bilo, da so estragol, $\beta$-ocimen in d-limonen glavne sestavine. Zaplinjevanje $\mathrm{z}$ eteričnim oljem je imelo znaten toksični učinek na škodljivi žuželki. Smrtnost žuželk je bila odvisna od koncentracije eteričnega olja in časa izpostavitve. Analiza Probit je pokazala, da je vrsta $R$. dominica $\mathrm{z}$ manjšimi $\mathrm{LC}_{50}$ vrednostmi bolj občutljiva kot vrsta T. castaneum. Glede na to bi lahko eterično olje iz vrtnega šetraja $z$ veliko vsebnostjo fenilpropanoidov in terpenov priporočili kot učinkovito in naravno alternativo škodljivim kemikalijam pri zatiranju omenjenih škodljivcev.

Ključne besede: eterično olje; estragol; Satureja hortensis; zaplinjevanje; škodljivi hrošči

1 University of Mohaghegh Ardabili, Moghan College of Agriculture and Natural Resources, Ardabil, Iran

2 Corresponding author, e-mail: ebadollahi@uma.ac.ir 


\section{INTRODUCTION}

Secondary metabolites announce the evolution of chemical defenses in plants which are often formed as by-products throughout the production of primary metabolites. Secondary metabolites have several essential roles especially in the protection against herbivores and in the attraction of pollinators' (Dinan, 1995; Bohinc et al., 2012). Plant-derived essential oils as well-known secondary metabolites can be produced in several aerial parts including leaves, flowers, seeds, stems and the roots of aromatic plants. Essential oils are generally composed of isoprene units as terpenes and phenylpropane (Bakkali et al., 2008). Although terpenes such as monoterpenes ( 2 units of isoprene, $\mathrm{C}_{10}$ ), sesquiterpenes ( 3 units of isoprene, $\mathrm{C}_{15}$ ), and diterpenes (4 units of isoprene, $\mathrm{C}_{20}$ ) have a high quantity, the monoterpenoids (oxygenated monoterpenes) are often the most components of the many essential oils (Breitmaier, 2006; Abdel-Tawab, 2016). Along with the application of essential oils in the perfumery and pharmaceutical industries, their lethal and sub-lethal effects especially fumigant toxicity of essential oils have been approved toward different class and orders of main insect and acari herbivores (RegnaultRoger et al., 2012; Rojht et al., 2012; Ebadollahi \& JalaliSendi, 2015).

Summer savory [Satureja hortensis L. (Lamiaceae)], as an aromatic spice and food preservative, widely distributed and/or cultivated in many countries. It used in Iranian traditional medicine to treat intestinal and stomach disorders such as indigestion and diarrhea, muscle pain, thrombosis, and cardiovascular diseases (Hajhashemi et al., 2000; Yazdanparast et al., 2008). Moreover, along with antibacterial, antifungal, antioxidant, and cytotoxic activities of $S$. hortensis, its potential on the insect pest management have also been documented (Mahboubi \& Kazempour, 2011; Miladi et al., 2013; Gombač \& Trdan, 2014; Farzaneh et al., 2015; Ghorbanpour et al., 2016).

$R$. dominica (lesser grain borer) and T. castaneum (red flour beetle) are among the cosmopolitan serious pests of stored-products such as cereal and legume grains, dried fruits, spices, flours, leather, and even packaging materials made from wood and paper. Further, the quality of infested products strongly reduces due to the residues of insect bodies and their unpleasant smell (Villaverde et al., 2007; Edde, 2012).

As part of a program aimed at studying the insecticidal activity and chemical composition of plant essential oils, we have assessed the fumigant toxicity and chemical profile of $S$. hortensis essential oil against $R$. dominica and T. castaneum. Hope the range of introduced active bioagents derived from aromatic plants has extended by the results of the present study.

\section{MATERIALS AND METHODS}

\subsection{ESSENTIAL OIL EXTRACTION AND ANALY- SIS}

Fresh $10 \mathrm{~cm}$ aerial parts from the shoots of $S$. hortensis were sampled for essential oil extraction. The specimens were collected during April and May 2019 from Parsabad region (Latitude: $39^{\circ} 38^{\prime} \mathrm{N}$, Longitude: $47^{\circ} 52^{\prime} \mathrm{E}$, and height: $52 \mathrm{~m}$ ), Ardebil province, Iran. The samples were dried at room temperature within a week and then ground using an electric grinder. Fifty grams ground plant material was poured into a Clevenger apparatus equipped with a $1000 \mathrm{ml}$ balloon. The essential oil was extracted within $3 \mathrm{~h}$ and the obtained oil was stored in a refrigerator at $4{ }^{\circ} \mathrm{C}$.

Chemical profile of the $S$. hortensis essential oil was assessed using a gas chromatographic system (Agilent model 7890B) equipped with the mass spectrometer detector (Agilent model 5977A) according to Ebadollahi et al. (2017): chromatographic separation was performed on the HP-5MS (5 \% phenyl-methyl-polysiloxane) capillary column ( $30 \mathrm{~m}$ length, $0.25 \mathrm{~mm}$ internal diameter, and $0.25 \mu \mathrm{m}$ film thickness) with $70 \mathrm{eV}$ ionization energy. The injected volume was $1.0 \mu \mathrm{l}$ with $280^{\circ} \mathrm{C}$ temperature. The temperature program of the column was set from 50 to $350{ }^{\circ} \mathrm{C}$. Helium (99.999 \%) was used as a carrier gas at $1 \mathrm{ml}$ minute $^{-1}$. The component was identified by comparison of their mass spectra with those from Wiley's MS library (7th edition) and NIST (National Institute of Standards Technology) in the library.

\subsection{TESTED INSECTS}

The adult insects of $R$. dominica were obtained from the colonies at the Department of plant protection, University of Mohaghegh Ardebili, Ardabil, Iran. The adult insects of T. castaneum were collected from contaminated wheat grains in the warehouses of Parsabad city (Latitude: $39^{\circ} 38^{\prime} \mathrm{N}$, Longitude: $47^{\circ} 52^{\prime} \mathrm{E}$, and height: $52 \mathrm{~m}$ ), Ardabil province, Iran. Adult insects were separately released on wheat grains in the breeding container. Adult insects were removed $48 \mathrm{~h}$ later and grains with insects' eggs were kept in an incubator at $25 \pm 2{ }^{\circ} \mathrm{C}$ and $65 \pm 5 \%$ relative humidity in dark (Arnaud et al., 2005). Synchronized adult insects with 1 - 7 old-days were selected.

\subsection{BIOASSAY}

The fumigation bioassay was done according to the study of Ebadollahi (2018): twenty adults of both insects 
were separately located in $340 \mathrm{ml}$ fumigant chambers. The tested concentrations of essential oil, based on the preliminary experiments, were from 11.76 to $47.06 \mu \mathrm{ll}^{-1}$ and from 21.00 to $55.15 \mu \mathrm{l} \mathrm{l}^{-1}$ for $R$. dominica and T. castaneum, respectively. The essential oil concentrations were poured on the $2 \times 3 \mathrm{~cm}$ piece of filter papers which were sealed to the inside of the container lids and the lids were closed using parafilm. Experiments were conducted for control groups without adding essential oil concentration. Each treatment was repeated 4 times and the insects' mortality was documented after 24,48 and $72 \mathrm{~h}$ intervals.

\subsection{STATISTICAL ANALYSIS}

Variance analysis was used to assess the significant effects of essential oils' concentrations and the exposure times. To compare the effects of independent factors concentration and exposure time on the insects' mortality, the $\omega^{2}$ comparison was used. Calculation of lethal concentrations (LC), lethal times (LT) and linear regression analysis along with heterogeneity of the data by a Chisquared test were done using SPSS software version 24 (IBM, Chicago, USA).

\section{RESULTS}

\subsection{CHEMICAL COMPOSITION OF ESSENTIAL OIL}

Chemical analysis of $S$. hortensis essential oil identified 17 components at $99.21 \%$, in which $83.02 \%$ are phenylpropanoid constituents. Five different groups of terpenes were also recognized in the essential oil, in which the monoterpene hydrocarbons $(15.38 \%)$ had the highest amount followed by sesquiterpenoids (0.43\%), monoterpenoids $(0.26 \%)$, a sesquiterpene hydrocarbon $(0.08 \%)$, and a diterpene $(0.04 \%)$. Estragole $(82.10 \%)$ as

Table 1: Chemical composition of the essential oil isolated from Iranian Satureja hortensis

\begin{tabular}{|c|c|c|c|}
\hline Compound & Retention Time (minute) & Formula and Classification & Percentage \\
\hline a-Pinene & 5.30 & $\mathrm{C}_{10} \mathrm{H}_{16}{ }^{\text {мн }}$ & 0.91 \\
\hline Camphene & 5.57 & $\mathrm{C}_{10} \mathrm{H}_{16}{ }^{\mathrm{MH}}$ & 0.04 \\
\hline Sabinene & 6.03 & $\mathrm{C}_{10} \mathrm{H}_{16}{ }^{\mathrm{MH}}$ & 0.06 \\
\hline$\beta$-Pinene & 6.09 & $\mathrm{C}_{10} \mathrm{H}_{16}{ }^{\mathrm{MH}}$ & 0.09 \\
\hline$\beta$-Myrcene & 6.33 & $\mathrm{C}_{10} \mathrm{H}_{16}{ }^{\mathrm{MH}}$ & 0.12 \\
\hline d-Limonene & 7.08 & $\mathrm{C}_{10} \mathrm{H}_{16}{ }^{\mathrm{MH}}$ & 2.25 \\
\hline$\beta$-Ocimene & 7.46 & $\mathrm{C}_{10} \mathrm{H}_{16}{ }^{\text {мH }}$ & 11.86 \\
\hline a-Terpinene & 8.27 & $\mathrm{C}_{10} \mathrm{H}_{16}{ }^{\mathrm{MH}}$ & 0.05 \\
\hline Rosefuran & 8.43 & $\mathrm{C}_{10} \mathrm{H}_{14} \mathrm{O}^{\mathrm{M}}$ & 0.08 \\
\hline Estragole & 11.51 & $\mathrm{C}_{10} \mathrm{H}_{12} \mathrm{OPh}$ & 82.10 \\
\hline E,E-2,6-Dimethyl-3,5,7-octatriene-2-ol & 11.54 & $\mathrm{C}_{10} \mathrm{H}_{16} \mathrm{O}^{\mathrm{M}}$ & 0.07 \\
\hline Bornyl acetate & 14.23 & $\mathrm{C}_{12} \mathrm{H}_{20} \mathrm{O}_{2}{ }^{\mathrm{M}}$ & 0.11 \\
\hline Methyl Eugenol & 18.71 & $\mathrm{C}_{11} \mathrm{H}_{14} \mathrm{O}_{2} \mathrm{Ph}$ & 0.92 \\
\hline Germacrene-D & 21.05 & $\mathrm{C}_{15} \mathrm{H}_{24}{ }^{\mathrm{sH}}$ & 0.08 \\
\hline Spathulenol & 23.76 & $\mathrm{C}_{15} \mathrm{H}_{24} \mathrm{O}^{\mathrm{s}}$ & 0.31 \\
\hline Caryophyllene oxide & 23.89 & $\mathrm{C}_{15} \mathrm{H}_{24} \mathrm{O}^{\mathrm{s}}$ & 0.12 \\
\hline Eicosane & 32.78 & $\mathrm{C}_{20} \mathrm{H}_{42}{ }^{\mathrm{DH}}$ & 0.04 \\
\hline MH: Monoterpene Hydrocarbon & & & 15.38 \\
\hline M: Monoterpenoid & & & 0.26 \\
\hline SH: Sesquiterpene Hydrocarbon & & & 0.08 \\
\hline S: Sesquiterpenoid & & & 0.43 \\
\hline DH: Diterpene Hydrocarbon & & & 0.04 \\
\hline Ph: Phenylpropanoid & & & 83.02 \\
\hline Total & & & 99.21 \\
\hline
\end{tabular}


Table 2: Results of the variance analysis of S. hortensis essential oil fumigation on the adults of R. dominica and T. castaneum after 24, 48 and 72-h exposure times

\begin{tabular}{llllll}
\hline Insect & Source of Variation & $\mathrm{df}$ & $F$ & $p$-value & $\omega^{2}$ \\
\hline R. dominica & Concentration & 4 & $467.987^{*}$ & $<0001$ & 22.516 \\
& Time & 2 & $155.009^{*}$ & $<0001$ & 3.713 \\
& Time $\times$ Concentration & 8 & 1.594 & 0.154 & 0.057 \\
\multirow{3}{*}{ T. castaneum } & Concentration & 4 & $324.572^{\star}$ & $<0001$ & 17.793 \\
& Time & 2 & $142.271^{*}$ & $<0001$ & 3.884 \\
& Time $\times$ Concentration & 8 & 1.106 & 0.377 & 0.012 \\
\hline
\end{tabular}

* Significant at $\alpha=1 \%$
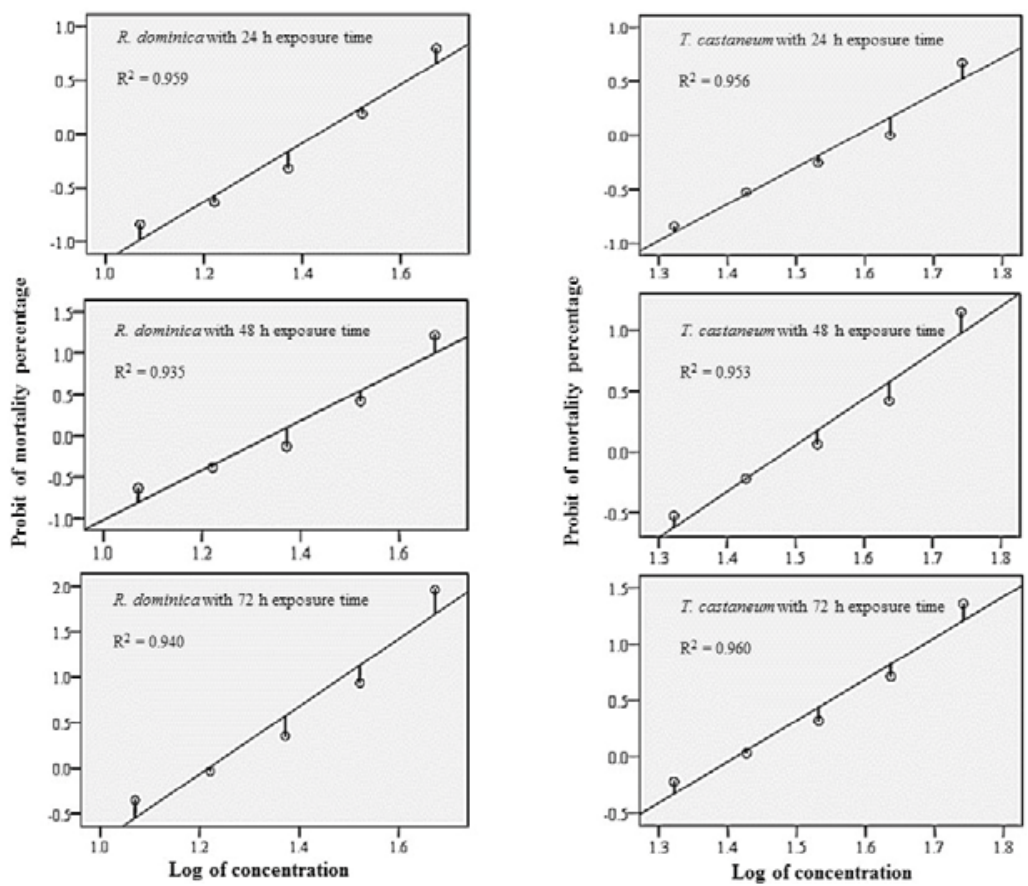

Figure 1: Concentration - mortality lines for fumigant toxicity of $S$. hortensis essential oil against the adults of $R$. dominica and T. castaneum after 24, 48 and 72-h exposure times

a phenylpropanoid constituent had the highest amount and monoterpene hydrocarbons $\beta$-ocimene (11.86\%), and dl-limonene $(2.25 \%)$ were in the next points (Table $1)$.

\subsection{FUMIGANT TOXICITY}

Results of the fumigant toxicity indicated that essential oil of Iranian S. hortensis had considerable toxicity on the $R$. dominica and T. castaneum adults. The results of variance analysis were summarized in Table 2. Concentrations of essential oil and exposure times had statistically significant effects on the insects' mortality but their interaction wasn't significant. Furthermore, based on the $\omega^{2}$ values, among these factors, the effect of essential oil concentration was more effective.

The calculated $\mathrm{R}^{2}$ values for concentrations-mortality correlation were $0.959,0.935$ and 0.940 for $R$. dominica and $0.956,0.953$ and 0.960 for $T$. castaneum after 24,48 and 72-h exposure times, respectively. So, there is a direct correlation between the concentrations of essential oil and mortality of both insects (Figure 1).

Probit analysis indicated the calculated $\mathrm{LC}_{50}$ values (lethal concentration to kill $50 \%$ of tested insects) of essential oil were significantly decreased from $24 \mathrm{~h}$ to $72 \mathrm{~h}$ for both insects (Table 3). For example, the $24 \mathrm{~h}-\mathrm{LC}_{50}$ value of essential oil with $95 \%$ confidence limits was 27.212 
Table 3: Results of Probit analysis for fumigant toxicity of S. hortensis against the adults of R. dominica and T. castaneum

\begin{tabular}{llllll}
\hline Insect & $\begin{array}{l}\text { Time } \\
(\mathrm{h})\end{array}$ & $\begin{array}{l}\mathrm{LC}_{50}(95 \% \text { confidence limits }) \\
\left(\mu \mathrm{l}^{-1}\right)\end{array}$ & $\begin{array}{l}\chi^{2} \\
(\mathrm{df}=3)\end{array}$ & Slope $\pm \mathrm{SE}$ & Significance $^{*}$ \\
\hline R. dominica & 24 & $27.212(24.657-30.361)$ & 3.893 & $2.740 \pm 0.294$ & 0.273 \\
& 48 & $22.193(20.140-24.385)$ & 7.062 & $2.897 \pm 0.298$ & 0.070 \\
& 72 & $16.466(12.128-20.013)$ & 5.830 & $3.321 \pm 0.329$ & 0.120 \\
T. castaneum & 24 & $38.908(35.951-42.688)$ & 3.425 & $3.386 \pm 0.412$ & 0.331 \\
& 48 & $30.757(28.377-33.070)$ & 3.810 & $3.691 \pm 0.419$ & 0.283 \\
& 72 & $25.747(23.020-28.021)$ & 2.745 & $3.506 \pm 0.429$ & 0.433 \\
\hline Insect & Concentration & $\mathrm{LT}_{50}(95 \%$ confidence limits $)$ & $\chi^{2}$ & & \\
$\left(\mu \mathrm{l} \mathrm{l}^{-1}\right)$ & $(\mathrm{h})$ & $(\mathrm{df}=1)$ & Slope \pm SE & Significance * \\
R. dominica & 47.06 & $10.301(2.944-16.210)$ & 1.765 & $2.060 \pm 0.515$ & 0.184 \\
T. castaneum & 55.15 & $12.682(5.479-18.103)$ & 2.023 & $2.282 \pm 0.503$ & 0.155 \\
\hline
\end{tabular}

* Since the significance level is greater than 0.05 , no heterogeneity factor is used in the calculation of confidence limits. The number of insects for calculation of $\mathrm{LC}_{50}$ values is 400 for each time. The number of insects for calculation of $\mathrm{LT}_{50}$ values is 240 for each concentration.

(24.657 - 30.361) $\mu \mathrm{l} \mathrm{l}^{-1}$ which was decreased to 16.466 (12.128 - 20.013) $\mu \mathrm{l} \mathrm{l}^{-1}$ after $72 \mathrm{~h}$. Further, according to Table 3 , adults of $R$. dominica with low $\mathrm{LC}_{50}$ values were significantly susceptible than $T$. castaneum adults to the $S$. hortensis essential oil at all exposure times.

The lethal times to kill $50 \%$ of tested insects $\left(\mathrm{LT}_{50}\right.$ values) are also shown in Table 3 . At a high tested concentration of $S$. hortensis essential oil $\left(47.06 \mu \mathrm{l} \mathrm{l}^{-1}\right)$, the $\mathrm{LT}_{50}$ value was $10.301(2.944-16.210)$ h against $R$. dominica adults. This value for T. castaneum adults with a concentration of $55.15 \mu \mathrm{ll}^{-1}$ was calculated as 12.682 (5.479 - 18.103) h.

\section{DISCUSSION}

The composition of $S$. hortensis essential oil have been investigated in the previous studies; carvacrol (11.0\%), $\rho$-cymene (19.6\%), sabinene (4.4\%), $\gamma$-terpinene $(16.0 \%)$, and thymol $(28.2 \%)$ were found as major compounds by Mahboubi and Kazempour (2011). Thymol, $\rho$-cymene, $\gamma$-terpinene, and carvacrol were not detected in the present study but a trace of sabinene $(0.06 \%)$ was determined. In contrast, estragole and $\beta$-ocimene as major components of present work were not detected in the study of Mahboubi and Kazempour (2011). Farzaneh et al. (2015) showed carvacrol (48.0\%), $\rho$-cymene $(11.7 \%)$, myrcene $(2.5 \%)$, a-pinene $(2.5 \%)$, $\gamma$-terpinene $(24.2 \%)$ were the main components. From these constituents, myrcene $(0.12 \%)$ and $\alpha$-pinene $(0.91 \%)$ with different amounts were recognized in the essential oil of present study. In the other study, Miladi et al. (2013) also revealed that monoterpenoids (59.11\%) were the main chemical class of $S$. hortensis essential oil which is parallel with our results but they announced other components such as carvacrol, $\beta$-caryophyllene, $p$ cymene, and $\gamma$-terpinene. In contrary, Mohammadhosseini and Beiranvand (2013) showed that the monoterpene hydrocarbons such as myrcene, $\alpha$-pinene, $\beta$-pinene, $\alpha$-terpinene, and $\alpha$-thujene had the highest amount in the S. hortensis essential oil. These differences in the chemical profile of $S$. hortensis essential oil in the present and above-mentioned studies can be due to the variations in some of the influential factors, such as geographical and growing conditions, drying and extraction methods, ontogenetic stages, and season (Sefidkon et al., 2006; Pfefferkorn et al., 2008; Rezvanpanah et al., 2011; Ghorbanpour et al., 2016).

Insecticidal properties of S. hortensis essential oil were acknowledged in some recent studies; appropriate fumigant toxicity of this oil was proved against Mediterranean flour moth [Ephestia kuehniella (Zeller, 1879)], Indianmeal moth [Plodia interpunctella (Hubner, 1813)], and T. castaneum (Mollaei et al., 2011). The calculated 48 h-LC ${ }_{50}$ value for T. castaneum in this work $\left(192.350 \mu \mathrm{ll}^{-1}\right)$ is much higher than the corresponding $\mathrm{LC}_{50}$ in the present study $\left(30.757 \mu \mathrm{l}^{-1}\right)$. In the study of Tozlu et al. (2011), the $S$. hortensis essential oil with a high amount of carvacrol, $\beta$-caryophyllene, $\mathrm{p}$-cymene, $\delta$-terpinene, and $\alpha$-terpinene was very toxic against the broad bean weevil [Bruchus dentipes (Baudi, 1886)]. They concluded that the $S$. hortensis essential oil toxicity is directly related to its components. Along with the fumigant toxicity of $S$. hortensis essential oil, the contact toxicity, repellency, and disruption in the enzymes' activity were also described (Mollaei et al., 2011; Heydarzade \& Moravvej, 2012; Magierowicz et al., 2019). The results of these studies indicated that $S$. hortensis essential oil has considerable 
insecticidal activities against stored-product insect pests which are in accordance with our findings.

Estragole or methyl chavicol, as two major compounds identified in the present study, is a GRAS (Generally Recognized As Safe) nominated material and approved for food procedure (De Vincenzi et al., 2000). Its name originates from "estragon" which is a French word of tarragon (Artemisia dracunculus L.) (Misztal et al., 2010). Along with cytotoxic and antimicrobial properties of estragole (Bagamboula et al., 2004; Andrade et al., 2015), toxicity of this compound has also been approved against some of damaging stored-product insect pests including T. castaneum, the rice weevil [Sitophilus oryza (Linnaeus, 1763)], the maize weevil [Sitophilus zeamais (Motschulsky, 1855)], the booklice [Liposcelis bostrychophila, Badonnel, 1931], the cigarette beetle [Lasioderma serricorne (Fabricius, 1792)], and the adzuki bean beetle [Callosobruchus chinensis (Linnaeus, 1758)] (Kim \& Ahn, 2011; Wang et al., 2011; Kim \& Lee, 2014; Guo et al., 2015). Furthermore, the insecticidal properties of other main components identified in the present study including d-limonene and $\beta$-ocimene were also documented (Tripathi et al., 2003; Guo et al., 2015; Kang et al., 2018). Accordingly, the fumigant toxicity of S. hortensis essential oil may be attributed to such constituents. However, the existence of synergistic effects between other compounds is also possible.

\section{CONCLUSION}

Synthetic pesticide residues can be found in different parts of our surrounding environment from water and soil to everybody's foods and even human breast milk samples (Damgaard et al., 2006; NicolopoulouStamati et al., 2016; Trdan, 2016). Regarding the pests' management, due to the overusing of synthetic chemicals, the other side-effects such as resurgence and outbreak of new pests, several pest-resistant reports on the different classes of synthetic pesticides, and detrimental effects on valuable noun-target organisms including parasitoids and predators have also been documented (Köhler et al., 2013; Cruz et al., 2017; Sudo et al., 2018). Therefore, urgent efficacious tools for the reduction of synthetic chemical utilization and for announcing ecofriendly agents with fewer public health risks are required. Because of the low toxicity to the mammals and pose a minimum risk, the plant essential oils considered safe (Viciolle et al., 2012). The prospective pesticidal activity of several plants essential oils have been stated in recent years (Isman \& Grieneisen, 2014), and the range of these eco-friendly bio-agents was extended in the present study through the introduction of Iranian phenyl- propanoid-rich summer savory as a toxic agent against two damaging coleopteran insect pests $R$. dominica and T. castaneum. However, based on the short residual lifetime (Isman, 2006), it is recommended that such essential oils be tested in the better applicable form such as "controlled release technique" through micro- and nanoencapsulation. Furthermore, the pesticidal ability of this plant essential oil on the other pests and its adverse effects on beneficial biocontrol agents should be more investigated.

\section{ACKNOWLEDEMENTS}

Present work financially supported by the University of Mohaghegh Ardabili, which is appreciated.

\section{REFERENCES}

Abdel-Tawab, H.M. (2016). Green pesticides: Essential oils as biopesticides in insect-pest management. Journal of Environmental Science and Technology, 9, 354-378. https://doi. org/10.3923/jest.2016.354.378

Andrade, T.C., De Lima, S.G., Freitas, R.M., Rocha, M.S., Islam, T., Da Silva, T.G. \& Militão, G.C. (2015). Isolation, characterization and evaluation of antimicrobial and cytotoxic activity of estragole, obtained from the essential oil of Croton zehntneri (Euphorbiaceae). Annals of the Brazilian Academy of Sciences, 87(1), 173-182. https://doi.org/10.1590/00013765201520140111

Arnaud, L., Brostaux, Y., Lallemand, S. \& Haubruge, E. (2005). Reproductive strategies of Tribolium flour beetles. Journal of Insect Science, 5, 33. https://doi.org/10.1093/jis/5.1.33

Bagamboula, C.F, Uyttendaele, M. \& Debevere, J. (2004). Inhibitory effect of thyme and basil essential oils, carvacrol, thymol, estragol, linalool and p-cymene towards Shigella sonnei and S. flexneri. Food Microbiology, 21, 33-42. https:// doi.org/10.1016/S0740-0020(03)00046-7

Bakkali, F., Averbeck, S., Averbeck, D. \& Idaomar, M. (2008). Biological effects of essential oils-A review. Food and Chemical Toxicology, 46, 446-475. https://doi.org/ 10.1016/j. fct.2007.09.106

Bohinc, T., Goreta, B.S., Ban, D. \& Trdan, S. (2012). Glucosinolates in plant protection strategies: a review. Archives of biological sciences, 64(3), 821-828. https://doi.org/10.2298/ ABS1203821B

Breitmaier, E. (2006). Terpenes: Flavors, Fragrances, Pharmaca, Pheromones. Wiley-VCH Verlag $\mathrm{GmbH}$ and CO., Weinheim. 214 pp. https://doi.org/10.1002/aoc.1209

Cruz, R.A., Zanuncio, J.C., Lacerda, M.C., Wilcken, C.F., Fernandes, F.L. \& Tavares, W.S. (2017). Side-effects of pesticides on the generalist endoparasitoid Palmistichus elaeisis (Hymenoptera: Eulophidae). Scientific Report, 7, 10064. https://doi.org/10.1038/s41598-017-10462-3

Damgaard, I.N., Skakkebaek, N.E., Toppari, J., Virtanen, H.E., Shen, H. \& Schramm, K.W. (2006). Persistent pesti- 
cides in human breast milk and cryptorchidism. Environmental Health Perspectives, 114, 1133-1138. https://doi. org/10.1289/ehp.8741

De Vincenzi, M., Silano, M., Maialetti, F. \& Scazzocchioa, B. (2000). Constituents of aromatic plants: II. Estragole. Fitoterapia, 71, 725-729. https://doi.org/10.1016/S0367-326X (00)00153-2

Dinan, L. (1995). A strategy for the identification of ecdysteroid receptor agonists and antagonists from plants. European Journal of Entomology, 92, 271-283. https://www.eje.cz/artkey/eje-199501-0031.php

Ebadollahi, A. \& Jalali-Sendi, J. (2015). A review on recent research results on bio-effects of plant essential oils against major Coleopteran insect pests. Toxin Reviews, 34(2), 7691. https://doi.org/10.3109/15569543.2015.1023956

Ebadollahi, A. (2018). Fumigant toxicity and repellent effect of seed essential oil of celery against lesser grain borer, Rhyzopertha dominica F. Journal of Essential Oil Bearing Plant, 21(1), 146-154. https://doi.org/10.1080/097206 0X.2018.1445036

Ebadollahi, A., Davari, M., Razmjou, J. \& Naseri, B. (2017). Separate and combined effects of Mentha piperata and Mentha pulegium essential oils and a pathogenic fungus $L e$ canicillium muscarium against Aphis gossypii (Hemiptera: Aphididae). Journal of Economic Entomology, 110(3), 10251030. https://doi.org/10.1093/jee/tox065

Edde, P.A. (2012). A review of the biology and control of Rhyzopertha dominica (F.) the lesser grain borer. Journal of Stored Product Research, 48, 1-18. https://doi.org/10.1016/j. jspr.2011.08.007

Farzaneh, M., Kiani, H., Sharifi, R., Reisi, M. \& Hadian, J. (2015). Chemical composition and antifungal effects of three species of Satureja (S. hortensis, S. spicigera, and S. khuzistanica) essential oils on the main pathogens of strawberry fruit. Postharvest Biology and Technology, 109, 145151. https://doi.org/j.postharvbio.2015.06.014

Ghorbanpour, M., Hadian, J., Hatami, M., Salehi-Arjomand, H. \& Aliahmadi, A. (2016). Comparison of Chemical compounds and antioxidant and antibacterial properties of various Satureja species growing wild in Iran. Journal of Medicinal Plants, 15, 58-72. http://jmp.ir/article-1-1465-en. html

Gombač, P. \& Trdan, S. (2014). The efficacy of intercropping with birdsfoot trefoil and summer savoury in reducing damage inflicted by onion thrips (Thrips tabaci, Thysanoptera, Thripidae) on four leek cultivars. Journal of plant diseases and protection, 121, 117-124. https://doi.org/10.1007/ BF03356499

Guo, S.S., You, C.X., Liang, J.Y., Zhang, W.J., Geng, Z.F., Wang, C.F., Du, S.S. \& Lei, N. (2015). Chemical composition and bioactivities of the essential oil from Etlingera yunnanensis against two stored product insects. Molecules, 20, 15735 15747. https://doi.org/10.3390/molecules200915735

Hajhashemi, V., Sadraei, H., Ghannadi, A.R. \& Mohseni, M. (2000). Antispasmodic and anti-diarrhoeal effect of Satureja hortensis L. essential oil. Journal of Ethnopharmacology, 71(1), 187-192. https://doi.org/10.1016/s03788741(99)00209-3

Heydarzade, A. \& Moravvej, G.H. (2012). Contact toxicity and persistence of essential oils from Foeniculum vulgare, Teucrium polium and Satureja hortensis against Callosobruchus maculatus (Fabricius) (Coleoptera: Bruchidae) adults. Turkish Journal of Entomology, 36(4), 507-518. https://dergipark.org.tr/en/pub/entoted/issue/5697/76163

Isman, M.B. \& Grieneisen, M.L. (2014). Botanical insecticide research: many publications, limited useful data. Trends in Plant Science, 19, 140-145. https://doi.org/10.1016/j. tplants.2013.11.005

Isman, M.B. (2006). Botanicals insecticide, deterrents and repellents in modern agriculture and increasing regulated world. Annual Review of Entomology, 51, 45-66. https://doi. org/10.1146/annurev.ento.51.110104.151146

Kang, Z.W., Liu, F.H., Zhang, Z.F., Tian, H.G. \& Liu, T.X. (2018). Volatile $\beta$-Ocimene can regulate developmental performance of peach Aphid Myzus persicae through activation of defense responses in Chinese cabbage Brassica pekinensis. Frontier in Plant Science, 9, 708. https://doi.org/10.3389/ fpls.2018.00708

Kim, D.H. \& Ahn, Y.J. (2001). Contact and fumigant activities of constituents of Foeniculum vulgare fruit against three coleopteran stored-product insects. Pest Management Science, 57, 301-306. https://doi.org/10.1002/ps.274

Kim, S. \& Lee, D. (2014). Toxicity of basil and orange essential oils and their components against two coleopteran stored products insect pests. Journal of Asia-Pacific Entomology, 17, 13-17. https://doi.org/ 10.1016/j.aspen.2013.09.002

Köhler, H.R. \& Triebskorn, R. (2013). Wildlife ecotoxicology of pesticides: can we track effects to the population level and beyond? Science, 341, 759-765. https://doi.org/10.1126/science.1237591

Magierowicz, K., Górska-Drabik, E. \& Sempruch, C. (2019). The insecticidal activity of Satureja hortensis essential oil and its active ingredient carvacrol against Acrobasis advenella (Zinck.) (Lepidoptera, Pyralidae). Pesticide Biochemistry and Physiology, 153, 122-128. https://doi.org/10.1016/j. pestbp.2018.11.010

Mahboubi, M. \& Kazempour, N. (2011). Chemical composition and antimicrobial activity of Satureja hortensis and Trachyspermum copticum essential oil. Iranian Journal of Microbiology, 3(4), 194-200. http://ijm.tums.ac.ir/index.php/ijm/ article/view/113

Miladi, H., Ben Slama, R., Mili, D., Zouari, S., Bakhrouf, A. \& Ammar, E. (2013). Chemical composition and cytotoxic and antioxidant activities of Satureja montana L. essential oil and its antibacterial potential against Salmonella Spp. Strains. Journal of Chemistry, https://doi. org/10.1155/2013/275698

Misztal, P.K., Owen, S.M., Guenther, A.B., Rasmussen, R., Geron, C., Harley, P., Phillips, G.J., Ryan, A., Edwards, D.P. \& Hewitt. C.N. (2010). Large estragole fluxes from oil palms in Borneo. Atmospheric Chemistry and Physics, 10, 43434358. https://doi.org/10.5194/acp-10-4343-2010

Mohammadhosseini, M. \& Beiranvand, M. (2013). Chemical composition of the essential oil from the aerial parts of Satureja hortensis using traditional hydrodistillation. Journal of Chemical Health Risks, 3(4), 49-60. https://doi. org/10.22034/jchr.2018.544047

Mollaei, M., Izadi, H., Dashti, H., Azizi, M. \& Ranjbar Karimi, 
R. (2011). Bioactivity of essential oil from Satureja hortensis (Laminaceae) against three stored-product insect species. African Journal of Biotechnology, 10(34), 6620-6627. https:// www.ajol.info/index.php/ajb/article/view/94654

Nicolopoulou-Stamati, P., Maipas, S., Kotampasi, C., Stamatis, P. \& Hens, L. (2016). Chemical pesticides and human health: the urgent need for a new concept in Agriculture. Frontier in Public Health, 4, 148. https://doi.org/10.3389/ fpubh.2016.00148

Pfefferkorn, A., Krüger, H. \& Pank, F. (2008). Chemical composition of Satureja hortensis L essential oils depending on ontogenetic stage and season. Journal of Essential Oil Research, 20, 303-305. https://doi.org/ 10.1080/10412905.2008.9700018

Regnault-Roger, C., Vincent, C. \& Arnason, J.T. (2012). Essential oils in insect control: low-risk products in a high-stakes world. Annual Review in Entomology, 57, 405-424. https:// doi.org/ 10.1146/annurev-ento-120710-100554

Rezvanpanah, S., Rezaei, K., Golmakani, M.T. \& Razavi, S.H. (2011). Antibacterial properties and chemical characterization of the essential oils from summer savory extracted by microwave-assisted hydrodistillation. Brazilian Journal of Microbiology, 42(4), 1453-1462. https://doi.org/10.1590/ S1517-838220110004000031

Rojht, H., Košir, I.J. \& Trdan, S. (2012). Chemical analysis of three herbal extracts and observation of their activity against adults of Acanthoscelides obtectus and Leptinotarsa decemlineata using a video tracking system. Journal of plant diseases and protection, 119(2), 59-67. https://doi. org/10.1007/BF03356421

Sefidkon, F., Abbasi, K. \& Khaniki, G.B. (2006). Influence of drying and extraction methods on yield and chemical composition of the essential oil of Satureja hortensis. Food Chemistry, 99(1), 19-23. https://doi.org/10.1016/j.foodchem.2005.07.026

Sudo, M., Takahashi, D., Andow, D.A. Suzuki, Y. \& Yamanaka, T. (2018). Optimal management strategy of insecticide resistance under various insect life histories: Heterogeneous timing of selection and interpatch dispersal. Evolutionary Applications, 11, 271-283. https://doi.org/10.1111/ eva. 12550

Tozlu, E., Cakir, A., Kordali, S., Tozlu, G., Ozer, H. \& Akcin, T.A. (2011). Chemical compositions and insecticidal effects of essential oils isolated from Achillea gypsicola, Satureja hortensis, Origanum acutidens and Hypericum scabrum against broadbean weevil (Bruchus dentipes). Scientia Horticulturae, 130(1), 9-17. https://doi.org/ 10.1016/j.scienta.2011.06.019

Trdan, S. (2016). Insecticides resistance. Rijeka: In Tech. https://www.intechopen.com/books/insecticides-resistance

Tripathi, A.K., Prajapati, V., Khanuja, S.P.S. \& Kumar, S. (2003). Effect of d-limonene on three stored-product beetles. Journal of Economic Entomology, 96, 990-995. https://doi.org/ 10.1603/0022-0493-96.3.990

Viciolle, E., Castilho, P. \& Rosado, C. (2012). In vitro and in vivo assessment of the effect of Laurus novocanariensis oil and essential oil in human skin. International Journal of Cosmetic Science, 34, 546-550. https://doi.org/ 10.1111/j.14682494.2012.00745.x

Villaverde, M.L., Juārez, M.P. \& Mijailovsky, S. (2007). Detection of Tribolium castaneum (Herbst) volatile defensive secretions by solid phase microextraction-capillary gas chromatography (SPME-CGC). Journal of Stored Product Research, 43, 540-545. https://doi.org/10.1016/j.jspr.2007.03.003

Wang, C.F., Yang, K., Zhang, H.M., Cao, J., Fang, R., Liu, Z.L., Du, S.S., Wang, Y.Y., Deng, Z.W. \& Zhou, L.G. (2011). Components and insecticidal activity against the maize weevils of Zanthoxylum schinifolium fruits and leaves. Molecules, 16, 3077-3088. https://doi.org/10.3390/molecules16043077

Yazdanparast, R. \& Shahriyary, L. (2008). Comparative effects of Artemisia dracunculus, Satureja hortensis and Origanum majorana on inhibition of blood platelet adhesion, aggregation and secretion. Vascular Pharmacology, 48, 32-37. https://doi.org/ 10.1016/j.vph.2007.11.003 